\title{
KARAKTERISTIK SEMEN SEGAR SAPI BANGSA LIMOUSIN DAN SIMMENTAL DI BALAI INSEMINASI BUATAN LEMBANG
}

\author{
Denilisvanti B. Muada, Umar Paputungan, Manopo J. Hendrik*, Santie H. Turangan \\ Fakultas Peternakan Universitas Sam Ratulangi Manado, 95115
}

\begin{abstract}
ABSTRAK
Penelitian ini bertujuan mengetahui karakteristik semen segar sapi bangsa Limousin dan Simmental yang ada di BIB Lembang. Dari hasil analisis dan pembahasan di peroleh bahwa karakteristik kedua bangsa sapi Limousin dan Simmental untuk frekuensi penampungan ejakulasi semen adalah berbeda nyata, dimana frekuensi ejakulasi lebih tinggi pada Simmental dibandingkan Limousin (rata-rata 5,37 dan 4,60), sedangkan volume, $\mathrm{pH}$ dan motilitas tidak menunjukan perbedaan nyata (volume berkisar 7,17 - 7,20 ml, pH 6,65 6.66 dan motilitas 58,08 - 59,29\%). Warna semen segar bangsa Limousin dan Simmental terlihat warna putih susu dan konsistensi semen segar bangsa Limousin dan Simmental adalah sedang. Persentase warna dan konsistensi tersebut dari kedua bangsa ini Simmental cenderung dominan. Bangsa Limousin menunjukan bahwa frekuensi penampungan ejakulasi semen dengan $\mathrm{pH}$ memiliki korelasi $-0,32$ yaitu semakin tinggi frekuensi penampungan ejakulasi semen, maka $\mathrm{pH}$ cenderung menurun (asam), tetapi frekuensi penampungan ejakulasi semen dengan motilitas memiliki korelasi 0,34 yaitu semakin banyak frekuensi penampungan ejakulasi semen, maka motilitas spermatozoa cenderung meningkat. Variabel motilitas memiliki korelasi $-0,49$ dengan $\mathrm{pH}$, yakni semakin tinggi $\mathrm{pH}$ (basa), motilitas
\end{abstract}

*Korepondensi (corresponding autor)

Email: manopo_hendrik@yahoo.com spermatozoa cenderung menurun. Bangsa Simmental menunjukan bahwa frekuensi penampungan ejakulasi semen dengan volume memiliki korelasi -0,40, yakni semakin tinggi frekuensi penampungan ejakulasi semen, semakin rendah volume semen. Frekuensi penampungan ejakulasi semen dengan motilitas memiliki korelasi 0,5 yakni semakin tinggi frekuensi penampungan ejakulasi semen, semakin tinggi pula motilitas spermatozoa.

Kata kunci: semen, ejakulasi, volume, warna, konsistensi, $\mathrm{pH}$, motilitas

\section{ABSTRACT}

FRESH

SEMEN CHARACTERISTICS OF LIMOUSIN AND SIMMENTAL BULLS AT THE ARTIFISIAL INSEMINATION CENTER, LEMBANG. This study was conducted to evaluate the characteristics of fresh semen in Limousin and Simmental bulls at the artificial insemination center in Lembang. Results of this study showed that ejaculation frequency of Simmental bull was significantly higher than that of Limousin with the average of 5.37 and 4.60, respectively. Variables of volume, $\mathrm{pH}$ and motility were not significantly different between both bulls with volume ranging of $7.17-7.20 \mathrm{ml}, \mathrm{pH}$ ranging of $6.65-6.66$ and motility ranging of $58.08-59.29 \%$, respectively. The fresh semen colour of 
Limousin and Simmental bulls were indicated by dominant color of milk white color. Semen consistency of fresh semen from both bulls was moderate. The ejaculation frequency and $\mathrm{pH}$ variables indicated the correlation of -0.32 in Limousine bulls, meaning that the higher the ejaculation frequency, the lower the $\mathrm{pH}$ (acid), but the ejaculation frequency and motility of semen had the correlation of 0,34 , indicating the more the semen ejaculation frequency, the higher the motility of spermatozoa. The motility of semen had the negative correlation with $\mathrm{pH}(-0.49)$. The higher the $\mathrm{pH}$ (base), the motility of spermatozoa tended to decline. Simmental bull showed also that semen ejaculation frequency with volume had correlation of 0.40 , indicating that the higher the semen ejaculation frequency yakni, the lower the semen volume. Semen ejaculation frequency had correlation of 0.5 with mortality, indicating that the higher the semen ejaculation frequency, the higher the motility of spermatozoa.

Keywords: Semen, ejaculation, volume, color, consistency, $\mathrm{pH}$, motility

\section{PENDAHULUAN}

Peningkatan kebutuhan daging sapi di Indonesia diikuti dengan peningkatan produksi daging sapi. Berdasarkan Badan Pusat Statistika 2014 menyebutkan bahwa produksi daging sapi tahun 2013 sebanyak 504.819 ton dan tahun 2014 sebanyak 539.965 ton, namun kebutuhan daging sapi Indonesia belum terpenuhi. Kondisi ini mengakibatkan pemerintah melakukan impor daging dan bakalan sapi potong dari Australia untuk memenuhi kebutuhan daging sapi di Indonesia. Upaya untuk mengurangi impor adalah pengembangan program pembibitan peternak rakyat yang dipadukan dengan program pembibitan berskala industri feedlot dengan pemanfaatan teknologi Inseminasi Buatan untuk meningkatkan efisiensi reproduksi ternak.

Inseminasi Buatan merupakan salah satu teknologi tepat guna yang dapat dimanfaatkan untuk meningkatkan produktifitas sapi dengan memanfaatkan potensi pejantan unggul agar dapat mengawini lebih dari satu induk dan dapat meningkatkan mutu genetik dari ternak tersebut. Penggunaan IB dinilai bermanfaat untuk meningkatkan kinerja dan potensi ternak, mempermudah tes progeni dan meningkatkan jumlah keturunan dari pejantan yang telah terbukti mempunyai sifat-sifat unggul untuk tujuan produksi tertentu.

Salah satu usaha untuk meningkatkan kualitas sapi adalah dengan memanfaatkan teknologi IB menggunakan sapi yang mempunyai kualitas genetik yang unggul, di antaranya sapi Limousin, sapi Simmental dan lain-lain. Balai Inseminasi Buatan Lembang bergerak dalam usaha memproduksi spermatozoa bibit unggul. 
Ternak sapi yang ada di BIB Lembang antara lain sapi Limousin dengan ciri-ciri yaitu badan kompak dan padat berwarna seluruhnya coklat muda, kuning agak kelabu (beige), kisaran merah gelap dan hitam. Cocok pada daerah yang curah hujan tinggi, dan juga cocok di daerah dengan iklim sedang. Keunggulan pejantan Limousin yaitu pertumbuhan cepat dengan pertambahan berat badan harian $(\mathrm{PBBH})$ 1,0-1,4 $\mathrm{kg}$, sedangkan umur 2 tahun beratnya mencapai 800-900 kg dan dewasa 1.000-1.100 kg, kualitas dagingnya baik dan dikenal serta disukai oleh peternak. Sapi Simmental ciricirinya yaitu badan berwarna merah bata, bentuk tubuh yang kekar dan berotot, muka, kaki, perut dan brisket pada umumnya berwarna putih. Keunggulan pejantan Simmental yaitu pertumbuhan cepat, pertambahan berat badan harian 0,9-1,2 kg, berat badan jantan umur 2 tahun mencapai 800-900 kg dan jantan dewasa mencapai 1.000- $1.200 \mathrm{~kg}$, karkas tinggi dengan sedikit lemak dan dual porpose (daging dan susu) serta pejantan Simmental dapat berkembang dengan baik hampir diseluruh Indonesia.

Semen segar dari pejantan-pejantan dapat di amati atau di uji kualitasnya baik secara makroskopis meliputi volume, warna, konsistensi dan $\mathrm{pH}$ dan secara mikroskopik salah satunya adalah motilitas.
Berdasarkan latar belakang penelitian di atas, maka yang menjadi perumusan masalah dalam penelitian ini adalah apakah karakteristik semen segar sapi bangsa Limousin dan Simmental yang ada di BIB Lembang memiliki kualitas yang baik.

Penelitian ini bertujuan adalah untuk mengetahui dan menguji karakteristik semen segar sapi bangsa Limousin dan Simmental yang ada di BIB Lembang.

Hasil penelitian ini diharapkan dapat memberikan informasi tentang ejakulasi dan karakteristik dari volume, warna, konsistensi, $\mathrm{pH}$ semen segar dan motilitas spermatozoa sapi bangsa Limousin dan Simmental yang ada di BIB Lembang dan dapat menambah wawasan pengetahuan dibidang reproduksi ternak.

\section{MATERI DAN METODE PENELITIAN}

Penelitian ini dilakukan pada bulan November 2016 selam 2 minggu.Penelitian ini dilakukan di Balai Inseminasi Buatan Lembang (BIB Lembang) dengan suhu $19^{\circ} \mathrm{C}$. Ternak yang digunakan dalam penelitian ini adalah sapi bangsa Limousin dan Simmental masing-masing sebanyak 
Limousin 45 ekor jantan dengan kisaran umur 5-10 tahun, dan juga Simmental 45 ekor jantan dengan kisaran 5-11 tahun.

Variabel yang diamati adalah frekuensi penampungan ejakulasi semen, volume, warna, konsistensi, $\mathrm{pH}$ semen dan motilitas spermatozoa. Data yang terkumpul dianalisis secara statistik deskriptif yaitu dengan tabulasi, rata-rata sampel, persentase, standar deviasi, dan koefisien keragaman, uji t dan korelasi.

\section{HASIL DAN PEMBAHASAN}

Hasil pengamatan langsung dan pengambilan data kualitas semen segar sapi bangsa Limousin dan Simmental di BIB Lembang meliputi ejakulasi, volume, warna, $\mathrm{pH}$ dan konsistensi dan motilitas. Karakteristik semen segar sapi bangsa Limousin dan Simmental dapat dilihat pada Tabel 1.

Rata-rata frekuensi penampungan ejakulasi semen Simmental 5,37 $\pm 2,10$ lebih tinggi dibandingkan dengan Limousin yang

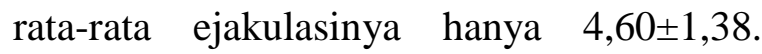
Menurut Foote (1969) dalam Toelihere (1981) rata-rata penampungan semen dalam seminggu untuk mempertahankan libido dan kualitas semen yang baik adalah 4 ejakulasi untuk ternak sapi. Koefesien keragaman frekuensi penampungan ejakulasi semen Limousin $30,00 \%$ atau berada pada keragaman yang sedang, sedangkan koefesien keragaman frekuensi penampungan ejakulasi semen Simmental $39,10 \%$ atau berada pada keragaman yang tinggi. Jika koefesien keragaman > 30\% maka dapat dilakukan seleksi.frekuensi penampungan ejakulasi semen kedua bangsa tersebut berbeda nyata $(\mathrm{p}<0,05)$. Perbedaan ini bisa terjadi karena dipengaruhi oleh, bangsa, berat badan, makanan dan juga manajemen penampungan (Melita et al., 2014).

Volume semen bangsa Limousin dan Simmental termasuk volume yang berada pada kisaran normal. Hal ini sesuai dengan Hartanti et al. (2012) yang melaporkan bahwa kisaran normal volume semen sapi berkisar antara 3,2-7,3 $\mathrm{ml}$ dan Arifiantini (2012), menyatakan bahwa rataan volume semen sapi adalah 4-8 ml. Hasil penelitian ini masih lebih tinggi jika dibandingkan dengan penelitian Aerens et al. (2012) bahwa rata-rata volume Limousin 6,308 \pm 1,386 dan Simmental $6,748 \pm 3,44$ dan penelitian Rahmawati et al. (2015), bahwa rata-rata volume semen Limousin 6,73 $\pm 1,11$ dan rata-

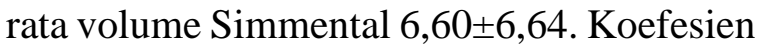
keragaman kedua bangsa tersebut berada pada keadaaan sedang dimana berada 
Tabel 1. Karakteristik semen segar sapi bangsa Limousin dan Simmental

\begin{tabular}{lcccc}
\hline \multicolumn{1}{c}{ Variabel } & \multicolumn{2}{c}{ Rata-rata \pm SD } & \multicolumn{2}{c}{ KK (\%) } \\
\hline & Limousin & Simmental & Limousin & Simmental \\
\hline $\begin{array}{l}\text { Frekuensi } \\
\text { ejakulasi semen jakulasi }\end{array}$ & $4,60 \pm 1,38$ & $5,37 \pm 2,10$ & 30,00 & 39,10 \\
Volume (ml) & $7,17 \pm 1,41$ & $7,20 \pm 1,49$ & 19,66 & 20,64 \\
Warna & Putih Susu & Putih Susu & - & - \\
Konsistensi & Sedang & Sedang & - & - \\
pH & $6,65 \pm 0,08$ & $6,66 \pm 0,05$ & 1,20 & 0,75 \\
Motilitas $(\%)$ & $59,29 \pm 13,87$ & $58,80 \pm 14,35$ & 23,39 & 24,70 \\
\hline
\end{tabular}

pada kisaran $15-30 \%$. Hasil uji thitung adalah sebesar 0,10 yang berarti lebih kecil dari 1,684 (0,05). Hal ini menunjukan bahwa kedua bangsa ini tidak berbeda nyata ( $>0,05)$. Penelitian ini sama dengan penelitian Sumeidiana et al. (2007) bahwa volumen semen antara bangsa sapi Simental, Limousin dan Brahman tidak ada perbedaan nyata.

Warna semen segar sapi bangsa Limousin dan Simmental dikategorikan dalam empat warna yaitu cream, putih susu, kuning dan abnormal. Warna putih susu dari semen segar pada kedua bangsa tersebut didukung oleh pendapat Sugiarto et al. (2014) dan Wahyudi et al. (2016) menyatakan bahwa warna semen segar sapi Limousin adalah putih susu sedangkan pemeriksaan warna semen segar pada sapi Simmental adalah warna putih susu (Wiratri et al., 2014). Warna semen putih susu masih dikatakan normal, hal ini didukung oleh pendapat Feradis (2010), bahwa semen sapi normal berwarna putih susu atau krem keputihan dan keruh.

Konsistensi atau derajat kekentalan pada kedua bangsa ini berada pada konsistensi sedang. Konsistensi sedang pada semen segar bangsa Limousin dan Simmental tergolong normal. Hal ini didukung oleh penelitian Sugiarto et al. (2014) dan Wahyudi et al. (2016) bahwa konsistensi Limousin adalah sedang dan juga Simmental dengan bobot badan yang berbeda memiliki kosistensi semen yang sedang (Adhyatma et al., 2012). Semen yang konsistensinya sedang adalah semen yang akan segera kembali ke dasar dengan kecepatan yang lebih lambat dibandingkan yang pertama, sebagian semen masih menempel di dinding 
tabung (Arifiantini, 2012).

Rata-rata $\mathrm{pH}$ kedua bangsa ini tergolong dalam keadaan normal karena berada pada kisaran 6,4-7,8 (Garner dan Hafez, 2000). Hal ini juga didukung dengan pendapat Arifiantini (2012) bahwa derajat keasaman semen mamalia berkisar antara 67,5. Jika dilihat pada koefesien keragaman pada Tabel 1, kedua bangsa tersebut berada pada keadaan keragaman yang rendah yaitu bangsa Limousin $1,20 \%$ dan Simmental $0,75 \%$ atau bisa dikatakan hampir seragam. Hasil uji t antara kedua bangsa tersebut adalah tidak berbeda $(p>0,05)$.

Rata-rata motilitas kedua bangsa ini masih tergolong baik sesuai dengan yang dilaporkan Garner dan Hafez (2000) pada sapi tropis bahwa motilitas spermatozoa berkisar antara $40-75 \%$ dan juga pendapat Toelihere (1993) motilitas inividu semen segar yaitu $50-80 \%$ spermatozoa progresif dan menghasilkan gerakan massa, namun tergolong rendah bila dibandingkan dengan hasil penelitian oleh Rahmawati et al. (2015) bahwa rata-rata motilitas spermatozoa bangsa Limousin adalah $63,81 \pm 6,18$ dan bangsa Simmental adalah 61,69 $\pm 10,09$. Hasil penelitian ini juga masih lebih rendah jika dibandingkan dengan pendapat Sarastina $e t$ al. (2012) dimana rataan motilitas spermatozoa pada sapi Limousin sebesar $80,72 \pm 6,34 \%$. Penelitian ini masih dikatakan lebih tinggi jika dibandingkan denganpendapat Sugiarto et al. (2014) bahwa motilitas individu Limousin yaitu $58 \pm 2,74$, dan pendapat Khairi (2016) bahwa motilitas pada Simmental dengan berat badan $910 \mathrm{~kg}$ dan $958 \mathrm{~kg}$ adalah 48,08\%. Koefesien keragaman untuk bangsa Limousin adalah sebesar 23,39\% dan Simmental adalah $24,70 \%$. Hal ini menunjukan bahwa keragaman motilitas kedua bangsa ini adalah sedang, karena berada pada kisaran 15-30\%. Hasil uji t antara kedua bangsa adalah tidak berbeda nyata atau non signifikan ( $p>0,05)$.

\section{Korelasi}

Hasil pengamatan terhadap pendugaan hubungan antara variable reproduksi untuk mengantisipasi, manipulasi salah satu peran variable agar mampu meningkatkan peran variabel lain yang berkorelasi.

\section{Hubungan Frekuensi Penampungan Ejakulasi Dengan Volume Semen Segar Sapi}

Berdasarkan hasil penelitian bahwa nilai korelasi frekuensi penampungan ejakulasi semen dengan volume semen segar 
Tabel 2.Korelasi antara variable reproduksi pada pejantan Limousin dan Simmental.

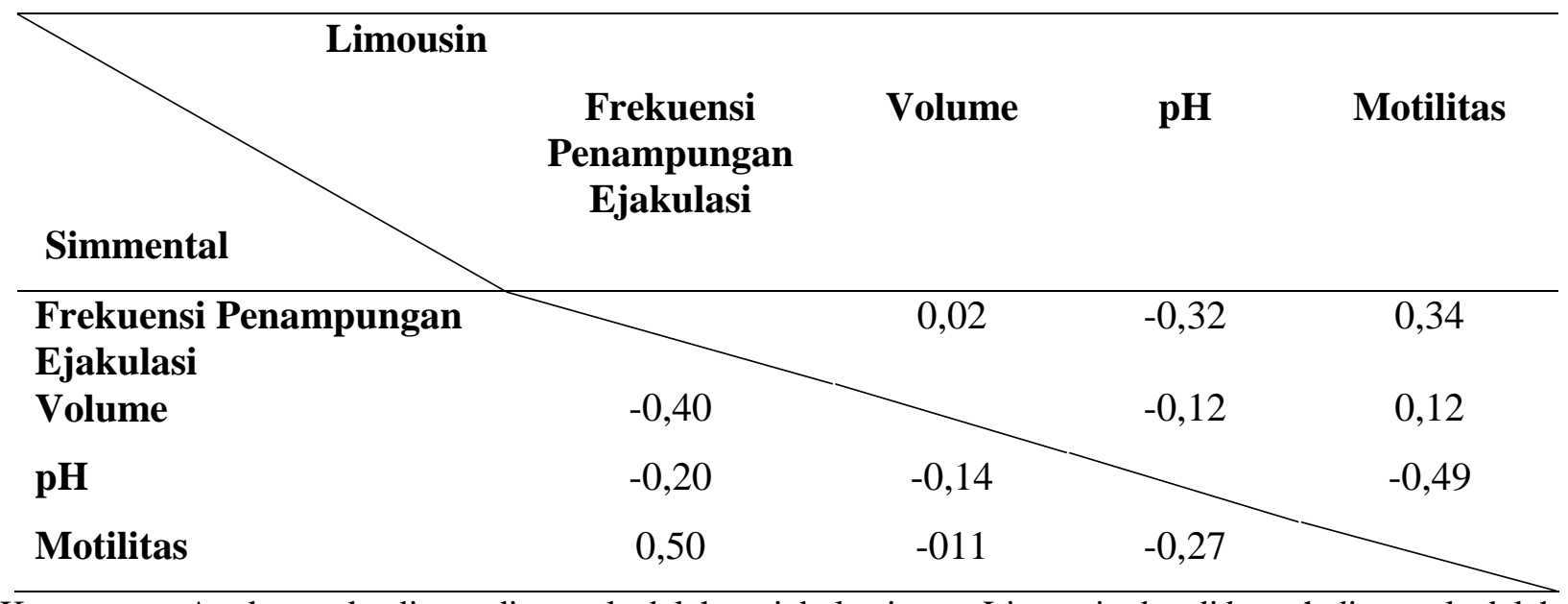

Keterangan: Angka-angka di atas diagonal adalah variabel pejantan Limousin dan di bawah diagonal adalah variable pejantan Simmental.

sapi bangsa Limousin yaitu 0,02 (Tabel 2) berarti tidak ada hubungan antara frekuensi penampungan ejakulasi semen dengan volume semen segar pada sapi bangsa Limousin, sedangkan bangsa Simmental menunjukan bahwa ejakulasi dengan volume memiliki korelasi -0,40 (Tabel 2) yaitu cenderung semakin tinggi frekuensi penampungan ejakulasi semen, semakin rendah volume semen. Bangsa Limousin dan Simmental memiliki korelasi yang berbeda. Hal ini bisa terjadi karena adanya berbedaan pada frekuensi penampungan ejakulasi semen, dimana bangsa Simmental yang lebih tinggi ejakulasinya dibandingkan dengan Limousin.Menurut Toelihere (1993) bahwa frekuensi yang terlalusering dalam satuan waktu terlalu pendek cenderung akan menurunkan salah satunya adalah volume semen. Hal ini sesuai dengan penelitian Melita et al. (2014) bahwa umur sapi pejantan dan frekuensi ejakulasi berpengaruh terhadap volume semen.

\section{Hubungan Frekuensi Penampungan Ejakulasi Dengan pH Semen Segar Sapi}

Hasil penelitian bahwa nilai korelasi frekuensi penampungan ejakulasi semen dengan $\mathrm{pH}$ semen segar sapi bangsa Limousin yaitu -0,32 (Tabel 2) yaitu semakin tinggi frekuensi penampungan ejakulasi semen cenderung $\mathrm{pH}$ menurun (asam) dan korelasi bangsa Simmental yaitu -0,2 (Tabel 2) yaitu memiliki korelasi yang lemah. Menurut Salisbury dan Van Demark (1985), $\mathrm{pH}$ dapat dipengaruhi oleh beberapa faktor, diantaranya adalah adanya aktivitas 
spermatozoa dalam menguraikan fruktosa, sehingga $\mathrm{pH}$ menjadi turun, kontaminasi dengan kuman sehingga $\mathrm{pH}$ naik, dan adanya perbedaan cara mengoleksi semen.

\section{Hubungan Frekuensi Penampungan Ejakulasi Dengan Motilitas Semen Segar Sapi}

Berdasarkan hasil penelitian untuk bangsa Limousin memiliki korelasi 0,34 (Tabel 2) yaitu semakin tinggi frekuensi penampunga ejakulasi semen, cenderung meningkat motilitas spermatozoa, sedangkan untuk bangsa Simmental memiliki korelasi 0,50 (Tabel 2), yaitu semakin tinggi frekuensi penampungan ejakulasi semen semakin tinggi pula motilitas spermatozoa. Menurut Toelihere (1993) faktor yang mempengaruhi motilitas spermatozoa adalah faktor makanan, karena motilitas spermatozoa memiliki hubungan dengan energy yang berasal dari pakan dan kematangan spermatozoa.

\section{Hubungan Volume Dengan pH Semen Segar Sapi}

Berdasarkan hasil penelitian bahwa nilai korelasi volume dengan $\mathrm{pH}$ semen segar sapi bangsa Limousinyaitu $-0,12$ (Tabel 2) dan nilai korelasi volume dengan $\mathrm{pH}$ semen segar sapi bangsa Simmental yaitu $-0,14$ (Tabel 2). Kedua bangsa ini menunjukan korelasi antara volume dengan $\mathrm{pH}$ sangat lemah. Menurut Salisbury dan Van Demark (1985), bahwa volume dipengaruhi oleh bobot badan, ukuran testis, lingkar skrotum, sedangkan $\mathrm{pH}$ dapat dipengaruhi oleh beberapa faktor, diantaranya adalah adanya aktivitas spermatozoa dalam menguraikan fruktosa, kontaminasi dengan kuman dan adanya perbedaan cara mengoleksi semen.

\section{Hubungan Volume Dengan Motilitas Spermatozoa Sapi.}

Berdasarkan hasil penelitian bahwa nilai korelasi volume dengan motilitasspermatozoa sapi bangsa Limousin yaitu 0,12 (Tabel 2) dan Simmental yaitu 0,11 (Tabel 2). Kedua bangsa ini menunjukan hubungan antara volume dengan motilitas spermatozoa yang lemah. Korelasi antar variabel dari kedua bangsa ini berbeda. Hal ini bisa dipengaruhi oleh bangsa dari pejantan yang ditampung semennya serta kondisi dari ternak (Feradis, 2010).

\section{Hubungan pH Dengan Motilitas Spermatozoa Sapi}

Berdasarkan hasil penelitian bahwa nilai korelasi $\mathrm{pH}$ dengan motilitasspermatozoa sapi bangsa Limousin yaitu -0,49 (Tabel 2), hal ini menunjukan bahwa semakin tinggi $\mathrm{pH}$ (basa) cenderung menurun motilitas 
spermatozoa dan untuk bangsa Simmental yaitu -0,27 (Tabel 2) memiliki korelasi yang lemah. Penelitian Sundari et al. (2013) bahwa $5,5 \%$ motilitas dipengaruhi oleh $\mathrm{pH}$.

\section{KESIMPULAN}

Dari hasil analisis dan pembahasan di peroleh bahwa karakteristik kedua bangsa yaitu Limousin dan Simmental untuk frekuensi penampungan ejakulasi semen adalah berbeda nyata, dimana menunjukan frekuensi ejakulasi lebih tinggi pada Simmental dibandingkan Limousin (rata-rata 5,37 dan 4,60), sedangkan volume, $\mathrm{pH}$ dan motilitas tidak menunjukan perbedaan nyata (volume berkisar 7,17-7,20, pH 6,65-6.66 dan motilitas 58,08-59,29\%). Warna semen segar bangsa Limousin dan Simmental yaitu warna putih susu dan konsistensi semen segar bangsa Limousin dan Simmental adalah sedang, namun persentase warna dan konsistensidari kedua bangsa ini Simmental cenderung dominan.

Bangsa Limousin menunjukan bahwa frekuensi penampungan ejakulasi semen dengan $\mathrm{pH}$ memiliki korelasi $-0,32$ yaitu semakin tinggi frekuensi penampungan ejakulasi semen cenderung $\mathrm{pH}$ menurun (asam), tetapi frekuensi penampungan ejakulasi semen dengan motilitas memiliki korelasi 0,34 yaitu semakin banyak frekuensi penampungan ejakulasi semen cenderung meningkat motilitas spermatozoa. Variable motilitas memiliki korelasi -0,49 dengan $\mathrm{pH}$, yaitu semakin tinggi $\mathrm{pH}$ (basa) cenderung menurun motilitas spermatozoa.

Bangsa Simmental menunjukan bahwa frekuensi penampungan ejakulasi semen dengan volume memiliki korelasi -0,40, yaitu cenderung semakin tinggi frekuensi penampungan ejakulasi semen, semakin rendah volume semen, namun frekuensi penampungan ejakulasi semen dengan motilitas memiliki korelasi 0,5 yaitu semakin tinggi frekuensi penampungan ejakulasi semen, semakin tinggi pula motilitas spermatozoa.

\section{DAFTAR PUSTAKA}

Adhyatma, M, I. Nurul dan Nuryadi.2012. Pengaruh bobot badan terhadap kualitas dan kuantitas semen sapi Simmental. Journal Ternak Tropika 14(2):53-62.

Aerens, C.D., M.N. Ihsan dan N. Isnaini. 2012. Perbedaan Kuantitatif dan Kualitatif Semen Segar pada Berbagai Sapi Potong. Malang.

Arifiantini, I. 2012. Teknis Koleksi dan Evaluasi Semen pada Hewan. IPB Press, Bogor.

Feradis. 2010. Bioteknologi Reproduksi pada Ternak. Alfabeta. Bandung. 
Garner, D.L, and E.S.E. Hafez. 2000. Spermatozoa and Seminal Plasma In: E.S.E Hafez (Ed). Reproduction Farm Animals. $7^{\text {th }}$ Ed. Lea and Febiger. Philadelphia. Hal 503-524.

Hartanti, D., E.T. Setiatin, dan Sutopo. 2012. Perbandingan penggunaan pengencer semen sitrat kuning telur terhadap persentase daya hidup spermatozoa sapi Jawa Brebes. Animal agri. Journal.1 (1) ; 33-42.

Khairi, F. 2016. Evaluasi reproduksi dan kualitas semen sapi simental terhadap tingkat bobot badan berbeda. Universitas Syiah Kuala. Banda Aceh. Jurnal Peternakan 13(2): 54-58.

Melita,.D., Dasrul dan M. Adam. 2014. Pengaruh umur pejantan dan frekuensi ejakulasi terhadap kualitas spermatozoa sapi Aceh. Jurnal Medika Veterinaria 8(1):15-19

Rahmawati, M.A., T. Susilawati dan M.N. Ihsan. 2015. Kualitas Semen dan Produksi Semen Beku pada Sapi dan Bulan Penampungan yang Berbeda. Jurnal ilmu-ilmu peternakan 25(3): 2536.

Salisbury, G. W. dan N. L. Van Demark. 1985. Fisiologi Reproduksi dan Inseminasi Buatan Pada Sapi. Gadjah Mada University Press, Yogyakarta.

Sarastina, T. Susilawati, dan G. Ciptadi. 2012. Analisa beberapa parameter motilitas spermatozoa pada berbagai bangsa sapi menggunakan Computer
Assisted Semen Analysis (Casa). J. Ternak Tropika 6(2): 1-12.

Sugiarto, N., T. Susilawati, dan S. Wahyuningsi. 2014. Kualitas semen cair sapi Limousin selama pendinginan menggunakan pengencer CEP-2 dengan penambahan berbagai konsentrasi sari kedelai. J. ternak tropika 15(1): 51-57

Sumeidiana, I., S. Wuwuh, dan E. Mawarti. 2007. Volume dan konsentrasi sperma sapi Simental, Limousine dan Brahman di Balai Inseminasi Buatan Unggaran.. Journal Indonesia Tropic Animal Agriculture 32(2):131-137.

Sundari, T.W., T.R. Tagam dan Maidaswar. 2013. Korelasi kadar pH semen segar dengan kualitas semen sapi Limousin di Balai Inseminasi Buatan Lembang Bandung. Journal Ilmiah Peternakan 1(3): 1043-1049

Toelihere, M.R. 1981. Inseminasi Buatan Pada Ternak. Angkasa. Bandung.

Toelihere, M.R. 1993. Fisiologi Reproduksi Ternak. Angkasa. Bandung.

Wahyudi, F.E., T. Susilawati, dan N. Isnaini. 2016. Penggantian bovine serum albumin pada CEP-2 dengan serum dara sapi Limousin pada suhu penyimpanan $3-5^{\circ} \mathrm{C}$. J. Ternak Tropika 17(2): 8-15.

Wiratri, V.D.B., T. Susilawati dan S. Wahjuningsih. 2014. Kualitas semen sapi Limousin pada pengencer yang berbeda selama pendinginan. Journal Ternak Tropika 15(1): 13-20 